\title{
Service Quality in Restaurants Operating in a Rural Area: The Case of Slovenian Istria
}

\author{
Marko Kukanja \\ University of Primorska, Faculty of Tourism Studies - Turistica, Slovenia \\ marko.kukanja@fts.upr.si \\ Tanja Planinc \\ University of Primorska, Faculty of Tourism Studies - Turistica, Slovenia \\ tanja.planinc@fts.upr.si
}

The purpose of this paper was to investigate service quality in restaurants operating in the rural area of Slovenian Istria. The DINESERV tool was used as a research instrument. The research sample consisted of 25 restaurant facilities and 250 valid questionnaires completed by domestic guests. Based on results of the exploratory factor analysis, two main factor groups that best explain domestic guests' quality perceptions in rural restaurant facilities were identified: (1) Empathy, Responsiveness, and Assurance (ERA) and (2) Tangibles. The results of our study are significantly different from those obtained in a previous study performed in the coastal area of Slovenian Istria (Kukanja \& Planinc, 2015), as they indicate a relatively bipolar and homogeneous service quality structure. This study is of great managerial interest at the micro (restaurant) and macro (destination) levels. Research results indicate that restaurant managers should emphasise the importance of the two identified quality dimensions (ERA and Tangibles) and continuously measure the level of their offerings. Accordingly, research results may also be implemented in future destination quality and development strategies. In terms of future research, it would be of great interest to see if similarities in guests' quality perceptions exist between Slovenian Istria and other competitive rural destinations.

Keywords: restaurant industry, service quality, DINESERV, rural areas, Slovenian Istria

https://doi.org/10.26493/2335-4194.12.147-159

\section{Introduction}

Understanding, achieving, and maintaining service quality are recognised as essential elements leading to the successful business of hospitality firms. Knowing guests' quality expectations is instrumental in developing a quality strategy for meeting and exceeding their expectations (Ryu \& Lee, 2017). Consequently, the efforts of service managers and researchers are directed to understanding and measuring guests' quality expectations and the quality of services provided.
In Slovenian Istria, several local tourism strategies primarily focus on general guidelines on how to develop different types of tourism in different geographical areas, towns, and municipalities (see https://www .las-istre.si; Mestna občina Koper, 2016; Turistično združenje Portorož, 2019). To the best of our knowledge, there are no studies that measure guests' perceptions of restaurant service quality on an operational (micro) level in rural areas. This is important because different restaurant facilities are the primary providers 
of the gastronomic services in rural Istria (Kukanja, 2016). The only study that measured domestic guests' quality perceptions in the area (coastal Istria) was conducted by Kukanja and Planinc in 2015, based on which the present study examines domestic guests' quality perceptions in restaurant facilities operating in the rural part of Slovenian Istria. It does this by applying the DINESERV tool. To determine guests' level of satisfaction with the quality of restaurant offerings, in our study, the SERVPERF (performance-based) approach was implemented, as previously suggested by Adil, Ghaswyneh, and Albkour (2013), Cronin and Taylor (1994), and Unuvar and Kaya (2017).

The purpose of this investigation is to explore domestic guests' quality perceptions in restaurant facilities operating in the rural part of Slovenian Istria. Based on previous research conducted in the area and the literature review (see Chapter 2), we formulated our main research question $(\mathrm{RQ})$ :

$\mathrm{RQ}$ How do domestic guests' perceive service quality in restaurants located in rural Istria?

This paper is divided into several sections. First, a brief review of service quality and rural tourism research is provided. Next, the research methodology is presented; followed by a presentation and discussion of results. In conclusion, suggestions for future research and useful information for restaurant managers are provided.

\section{Literature Review}

Service Quality

In recent decades, many academics (Hanks, Line, \& Kim, 2017; Kukanja, Gomezelj Omerzel, \& Kodrič, 2017; Nikbin, Marimuthu, \& Hyun, 2016) have examined the concept of service quality, its dimensions, and measurement methods. Among the various definitions proposed, the most widely used is the one proposed by Oliver (1980), which defines service quality as a gap between guests' quality expectations and quality perceptions (Park \& Jeong, 2019). Service quality is built on the concept of guest satisfaction. Satisfaction is most often defined as a post-purchase construct that is related to how a consumer likes or dislikes a service after experiencing it (Truong \& Foster,
2006). In terms of the restaurant industry, this postpurchase construct is primarily a result of pre-dining expectations and previous experiences. According to Oliver's (1980) disconfirmation theory, an individual guest's expectations are confirmed when the service performs as expected, negatively when the service performs worse than expected, and positively when the service performs as/or better than expected. Based on Oliver's theoretical concept, Parasuraman, Zeithaml, and Berry (1985) defined service quality as the ability of a service to fulfil and exceed guests' quality expectations. Because of the intangibility of services and guests' subjective perceptions of service quality, the delivery of high-quality services in the hospitality and tourism industry is a difficult task. In academic literature, several attempts have been made to capture and measure the essential components of service quality.

Parasuraman et al. $(1985 ; 1988)$ developed a fivestep model of service quality (also referred to as the Gap model) and proposed the SERVQUAL instrument, which measures service quality based on 22 quality indicators merged into five service quality attributes (quality dimensions): Responsiveness, Assurance, Tangibles, Empathy, and Reliability (also referred to as R A T E R). Similarly, Grönroos (1990) and Lehtinen and Lehtinen (1991) proposed two major components of service quality: the tangible (technical) and the intangible (functional) aspect of service quality. Following the pioneering work of Parasuraman et al. (1985) and Grönroos (1990), different scholars (Candido \& Morris 2000; Kukanja et al., 2017; Lin, Chan, \& Tsai, 2009) proposed alternative approaches to service quality measurement. For example, Lin et al. (2009) upgraded the traditional Importance Performance Analysis (IPA) with service quality gap evaluation and developed a new instrument called IPG A (Importance Performance Gap Analyses), Saeida Ardakani, Nejatian, Farhangnejad, and Nejati (2015) applied a fuzzy-logic method to service quality evaluation, while Kukanja et al. (2017) developed a service quality model based on the concept of Kotler's marketing mix. According to Ali, Hussain, Konar, and Jeon (2017), none of these alternative models received significant academic validation. Moreover, Ali et al. (2017) found that all alternative models were 
conceptually based on the gap model, as first proposed by Parasuraman et al. (1985). This view was also supported by Sharif and Kassim (2012), who state that the predominant quantitative measurement technique in hospitality and tourism research remains the SERVQUAL instrument with all its modifications. To adapt the SERVQUAL instrument to the specifics of the hospitality sector, many scholars modified the original SERVQUAL instrument and developed specific tailor-made models, such as:

- Lodgse Rv (Knutson, Stevens, Wullaert, Patton, \& Yokoyama, 1990): a modified version of the SERVQUAL instrument developed to measure service quality within the context of lodging (accommodation) settings;

- Dineserv tool (Stevens, Knutson, \& Patton, 1995): a modified version of the SERVQUAL instrument, developed for service quality evaluation in different restaurant settings.

- holserv (Wong Ooi Mei, Dean, \& White, 1999): a service quality instrument designed for quality evaluation in hotels;

- TANGSERV (Raajpoot, 2002): developed to measure the tangible aspect of service quality;

- SERVimperf model (Lin et al., 2009): this instrument combines service quality evaluation with importance measurement of different quality attributes;

- Grserv scale (Chen, Cheng, \& Hsu, 2013) designed for measuring guests' perceptions of service quality in green restaurants;

- MsQ (Eid \& Abdelkaber, 2017): a modified version of the SERVQUAL instrument adapted for measuring service quality in Muslim facilities;

Although restaurant managers can use simple techniques to assess guests' satisfaction (e.g., observations, conversations with employees and guests, hidden guests, etc.) service providers need standardised (quantitative) measurement tools to empirically evaluate, compare (benchmark), and understand the quality construct of provided services.

Service quality is not essential only for the success of restaurant firms, but also plays a vital role in the way tourists and/or visitors experience tourist destinations (Križman Pavlović \& Živolić, 2008). Consequently, more and more Destination Management Organisations (DMOS) are focusing on gastronomic tourism as a central element of a destinations' tourism product (Sukiman, Omar, Muhibudin, Yussof, \& Mohamed, 2013). Rural tourism destinations, in particular, are promoting local gastronomy (most often in the relationship between local food and tourism), as it highlights their distinctive food cultures, improves local sustainability standards, and strengths community wellbeing (Bellini \& Resnick, 2018; see https://igcat.org). In Slovenia, restaurant service quality, especially in the context of rural tourism, is relatively poorly analysed. This results in a lack of academic articles, although after the release of the Strategy of Gastronomy Development of Slovenia in 2006, a slight increase of research interest for gastronomy and restaurant-quality research was observed (Gačnik, 2012; Kerma \& Gačnik, 2015; Kukanja, 2016; 2017; Sanchez-Cañizares \& Castillo-Canalejo, 2015). Accordingly, there were more studies in the field of food and beverage (restaurant) management (Gričar \& Bojnec, 2009; Kukanja \& Planinc, 2018), farm tourism management (Bojnec \& Latruffe, 2013; Potočnik Slavič, 2014), and service quality management (Kukanja \& Planinc, 2015).

\section{The DINESERV Tool}

The original DINESERV tool included 40 service quality indicators. In the process of academic evaluation, the instrument was refined and revalidated. Today, the final version includes 29 items, which are captured into five RATER quality dimensions of the generic SERVQUAL instrument (Stevens et al., 1995). In their pilot study of service quality in Quick Service, Casual/Theme, and Fine Dining Restaurants, Knutson, Stevens, and Patton (1996) found that Reliability was the most important service quality dimension, followed by Tangibles, Assurance, Responsiveness, and Empathy. Later, Johns and Tyas (1996) used a modified version of the SERVQUAL instrument to evaluate the service quality of a contract catering company; interestingly, they found that other specific elements related to the quality of service staff and food, and not 
the RATER quality dimensions, were more important for delivering high-quality services.

Since the year 2000, there has been an increasing amount of academic research on restaurant quality management. In many studies, the DINESERV tool was used to assess the quality structure in different geographical areas. For example, Kim, McCahon, and Miller (2003) used the DINESERV tool to evaluate the service quality of a foreign-brand, casual dining restaurant in Korea. The factor analysis indicated that Tangibles had three sub-dimensions, and Responsiveness had a substantial overlap with Assurance. Results also revealed that gender, average spending per person (ASP), and the dining occasion significantly impacted guests' perceptions of service quality. Similarly, Bougoure and Neu (2010) used the DINESERV tool to assess service quality in the Malaysian fast food industry. The study confirmed the five-dimensional nature of the DINESERV tool. Later, Marković, Raspor and Šegarić (2010) analysed service quality in restaurants in Croatia, using a modified version of the DINESERV questionnaire and found that seven quality dimensions best explain guests' quality expectations in Croatian restaurants and only two dimensions influence guests' quality perceptions. Following the study of Marković et al. (2010), in 2015, Kukanja and Planinc conducted a cross-national comparison between the two neighbouring North Mediterranean tourist destinations: Opatija and Portorož and Piran. In their study, Kukanja and Planinc (2015) identified the importance of the very same quality dimensions as had previously been identified in the Opatija' study.

Similarly, Djekic et al. (2016) used the DINESERV tool to analyse restaurant guests' perceptions of service quality in different European cities: Belgrade (Serbia), Manchester (UK), Thessaloniki (Greece), and Porto (Portugal). The research results revealed that guests' from different cities showed significantly different perceptions regarding restaurant service quality. The authors also reported that the gender of guests' played a significant role in the perception of the interior, restroom, and service, while the age of respondents was a category with no significant difference concerning food quality, layout, restrooms, and service.

The results of presented studies indicate that the
RAT E R quality dimensions are not necessarily applicable in all restaurant facilities. Research results are not generalisable as restaurant guests may have different quality expectations from different restaurant facilities in different geographic areas. Nevertheless, the presented findings may aid in better understanding the specificity of the restaurant service quality. According to Hansen (2014), DINESERV has proven to be a reliable and valid measurement tool for assessing restaurant service quality. Following previous research, the DINESERV tool is applied in our study as well.

\section{Rural Areas and Rural Tourism}

According to Loureiro (2012), rural areas in postmodern society have grown in importance and appeal, since they have been perceived as green and unspoiled places. Conceptually, rural tourism may be regarded as tourism in the countryside, a form that embraces the rural environment as pivotal to the product offered (Loureiro, 2012). Rural tourism should be functionally rural, small in scale, traditional, organically and slowly growing, and managed by locals (Cawley \& Gillmor, 2008). According to Frochot (2005) and Ohe and Kurihara (2013), scholars have also become interested in rural tourism, as it was also recognised as a development tool for often economically depressed and underdeveloped rural areas. Rural tourism has also been identified as an opportunity to diversify the tourism product in terms of declining the importance of the mass sea, sand, and sun (sss) tourism destinations (Sharpley, 2002). Since the year 2000, there has been an increasing tendency among the urban population to choose rural zones as short-term tourism destinations (Loureiro, 2012). Service providers must correspondingly adapt to the current market situation. Guests in rural areas are becoming extremely demanding, as well as price- and quality-oriented (Sharpley, 2002). This results in an extremely competitive business environment, which is also dominated by powerful communication campaigns (Roberts, Hall, \& Morag, 2017) and strategically developed marketing actions (e.g., Green story of Slovenia; Discover green destinations and providers; Indulge in the most beautiful green adventures etc.) on different social media platforms (e.g., TripAdvisor, Booking.com, etc.). 


\section{Case Study Region}

This research was carried out in the rural area of Slovenian Istria, more specifically, in the hinterland of the municipalities of Piran, Koper, Izola, and Ankaran. Slovenian Istria (also referred to as the Slovenian Mediterranean), and especially its seaside riviera, are one of the most recognisable tourist destinations in the Eastern Adriatic region. Based on its long tradition of organised tourism, Slovenian Istria is still considered one of the most visited tourist destinations in the Republic of Slovenia (see https://www.stat.si/StatWeb/ en/Field/Index/24/66). In order to upgrade the market position of the entire area of Slovenian Istria, different projects and strategies have been applied by different municipalities and stakeholders, such as: the Eu cross-border project ' 365 Days of the Riviera,' which aimed to extend the summer season, the gastroproject 'Taste of Istria,' the wellness project 'Wellness Istria,' the wine path project 'Malvasia TourIstra,' and many others (see https://www.las-istre.si; https://www .turistica.si). All projects emphasised the importance of gastronomy and rural development for the overall tourism development of the entire region (Slovenian Istria). Further development of gastronomy in rural areas is also emphasised in different local strategies (e.g., Tourism Development Strategy of the Municipality of Piran until 2025 (Turistično združenje Portorož, 2019); Strategy of Development and Marketing of the Municipality of Koper until 2025 (Mestna občina Koper, 2016); and the National Strategy for the Sustainable Growth of Slovenian Tourism for 20172021 (Ministry of Economic Development and Technology, 2019). This is also important because gastronomy and rural (green) areas are important elements of Slovene national identity and critical components of its promotional campaigns at different national and international levels (Korez-Vide, 2017). Moreover, in 2018, Slovenia was officially appointed as the European (EU) Region of Gastronomy 2021 (see https://igcat.org).

\section{Methodology}

Research Process and Sample Description

In the first part of the study, qualitative research was performed to identify previous studies on restaurant quality in rural areas. Articles related to the research topic were retrieved in February 2019 from major academic databases for tourism and hospitality research, such as EвSCOHost (http://search.ebscohost.com/), Science Direct (http://sciencedirect.com/), and the Springer database (http://link.springer.com/). Keywords used to retrieve literature included: 'restaurant quality,' 'rural,' 'service quality,' 'DINEsERv', and 'service measurement.' The screening process started with reading titles and abstracts of each article. Although service quality is well researched in academic literature, surprisingly, there were relatively few studies focusing on restaurant service quality in rural areas. Articles and chapters in books that matched the topic of the research were included in the study in a logical manner (a total of nine publications). During the process of reviewing the academic literature, we also verified whether any previous studies had analysed restaurant service quality in Slovenian Istria. We found only one research study, conducted by Kukanja and Planinc in 2015. To the best of our knowledge, this is the only study that measured the quality of restaurant offerings in Slovenian Istria using the DINESERV methodology.

In the next part of the study, domestic guests' perceptions of restaurant service quality were analysed using the DINESERV tool. This instrument comprises 29 service quality indicators that correspond to the five quality dimensions of the generic SERVQUAL instrument (quality indicators are presented in Table 2). The level of guests' quality perceptions was measured on a five-point Likert-type ordinal scale, ranging from 1 (strongly agree) to 5 (strongly disagree). Although the generic DINESERV tool measures the differences between guests' quality expectations and perceptions to determine the level of the quality gap, in our study, we focused only on the analysis of guests' quality perceptions, as suggested by Adil et al. (2013). The research process used in this study was prepared by adapting the procedure used by Kukanja and Planinc (2015), who measured guests' quality expectations and perceptions in different restaurant settings located in the Portorož and Piran coastal area. Their study included 32 restaurant settings and 156 domestic guests.

In order to facilitate the comparison of results to Kukanja and Planinc's study, our study is predi- 
cated on the following research preconditions: time of field research (month of April); guest sample (domestic guests), and restaurant sample (only the following types of foodservice facilities were included in the study: restaurants (in Slovene restavracije), inns (in Slovene gostilne), and snack facilities (in Slovene okrepčevalnice) (see also Table 4). To determine the geographical (rural) area in which our research was conducted, we obtained information from the local development agency LAs Istre, which is responsible for Istrian rural development (see https://www.las-istre.si), and we consulted representatives of local tourism entrepreneurs operating in the area (M. Kozlovič Hrvatin, personal communication, 11 February 2019). Unfortunately, the exact number of restaurants located in rural Istria is unknown, although according to official data (see https://www.ajpes.si), 413 companies were operating in restaurant (Food \& Beverage) sector in the four Istrian municipalities (Piran, Koper, Izola, and Ankaran).

The fieldwork was performed by five pre-trained surveyors. Based on convenience sampling, questionnaires were distributed in 25 restaurants located in the Istrian hinterland. Each restaurant received ten questionnaires, which were completed by domestic guests. Residents were not included in the research. Before conducting the research, we obtained permission from the restaurant managers. Guests were asked to fill in a questionnaire after the service encounter. Although we used the performance-based scale, which (according to Adil et al. (2013)) considerably reduces the number of guests unwilling to collaborate in the study, some guests $(n=31)$ refused to participate for a variety of reasons. Therefore, the final analysis is based on 250 valid questionnaires. The Iв м SPSs software version 25.0 was used for the analysis of the results.

First, descriptive statistics analysis was used to describe respondents' demographic characteristics and to evaluate their quality perceptions (see Table 1). Next, exploratory factor analysis (EFA) was performed (see Tables 2 and 3 ) to assess the perceived quality structure. Principal component analysis with varimax rotation was used to derive the underlying dimensions of service quality. Variables with eigenvalues equal to or greater than 1, factor loadings above 0.3 , and fac-
Table 1 Socio-Demographic Data

\begin{tabular}{|c|c|c|c|}
\hline Variable & Item & $f$ & $\%$ \\
\hline \multirow[t]{2}{*}{ Gender } & Female & 126 & 50.4 \\
\hline & Male & 124 & 49.6 \\
\hline \multirow[t]{5}{*}{ Age } & $16-25$ & 77 & 30.8 \\
\hline & $26-35$ & 42 & 16.8 \\
\hline & $36-45$ & 41 & 16.4 \\
\hline & $46-55$ & 52 & 20.8 \\
\hline & More than 55 & 38 & 15.2 \\
\hline \multirow{5}{*}{$\begin{array}{l}\text { Level of } \\
\text { education }\end{array}$} & Elementary school & 19 & 7.6 \\
\hline & Vocational or secondary school & 134 & 53.6 \\
\hline & Associate degree & 19 & 7.6 \\
\hline & College or faculty degree & 61 & $24 \cdot 4$ \\
\hline & Master's degree or $\mathrm{PhD}$ & 17 & 6.8 \\
\hline \multirow{3}{*}{$\begin{array}{l}\text { Number } \\
\text { of visits }\end{array}$} & Once (first-time visitor) & 35 & 14.0 \\
\hline & Twice & 34 & 13.6 \\
\hline & Three times or more & 181 & 72.4 \\
\hline \multirow{4}{*}{$\begin{array}{l}\text { Purpose } \\
\text { of visit }\end{array}$} & Celebration & 37 & 14.8 \\
\hline & Business & 19 & 7.6 \\
\hline & Get together (socialising) & 78 & 31.2 \\
\hline & To dine (nutrition) & 116 & 46.4 \\
\hline
\end{tabular}

tors that contain more than three quality indicators were retained. To test the reliability of the scale and the inner consistency of extracted factors, the Cronbach alpha coefficients were calculated.

\section{Research Results}

In Table 1, the basic socio-demographic data are presented. As can be seen, the majority of respondents were in the 16-25 year group (the average is 38.3 years of age; standard deviation is 15.45), and the sample was almost equally composed of female (50.4\%) and male (49.6\%) guests. Most guests had finished vocational or secondary school. Next, the purpose of visit and the number of visits to the same restaurant were analysed. Most guests $(72.4 \%)$ visited the same restaurant three or more times with the purpose of dining (46.4\%).

The results presented in Table 2 show that all 29 DINESERV quality indicators were evaluated relatively highly (the average mean value is 4.31). Among the five service quality dimensions, the highest-rated dimen- 
Table 2 Analysis of Guests' Quality Perceptions

\begin{tabular}{|c|c|c|c|}
\hline Quality indicators & & (1) & (2) \\
\hline \multirow[t]{10}{*}{ Tangibles } & I 1 Visually attractive parking areas and building exteriors & 3.62 & 1.102 \\
\hline & I2 Visually attractive dining area & 4.04 & 0.997 \\
\hline & I3 Clean, neat and appropriately dressed staff & 4.44 & 0.722 \\
\hline & I 4 Restaurant's decor typical to its image and price range & 4.38 & 0.784 \\
\hline & I5 Easily readable menu & 4.64 & 0.606 \\
\hline & I6 Visually attractive menu & 4.41 & 0.724 \\
\hline & I7 Comfortable dining area & 4.06 & 0.961 \\
\hline & I 8 Clean restrooms & 4.12 & 1.009 \\
\hline & I9 Clean dining areas & $4 \cdot 39$ & 0.820 \\
\hline & I 10 Comfortable seats in the dining room & 3.98 & 0.994 \\
\hline \multirow[t]{5}{*}{ Reliability } & I11 Service in the promised time & 4.49 & 0.832 \\
\hline & I12 Quick correction of incorrect service & 4.46 & 0.817 \\
\hline & V13 Dependable and consistent restaurant & 4.57 & 0.686 \\
\hline & I 14 Accurate bill & 4.82 & 0.518 \\
\hline & I 15 Error-free served order (food) & 4.66 & 0.647 \\
\hline \multirow[t]{3}{*}{ Responsiveness } & I 16 Maintaining speed and quality of service during busy times & 4.04 & 1.019 \\
\hline & I17 Provision of prompt service & $4 \cdot 36$ & 0.849 \\
\hline & I18 Extra effort for handling special requests & 4.39 & 0.877 \\
\hline \multirow[t]{6}{*}{ Assurance } & I19 Employees can answer questions completely & 4.41 & 0.827 \\
\hline & I 20 Comfortable and confident feeling & 4.40 & 0.749 \\
\hline & I 21 Staff provide inf. about menu items, their ingred. and methods of preparation & 4.44 & 0.732 \\
\hline & I 22 Feeling safe & $4 \cdot 38$ & 0.778 \\
\hline & I 23 Well-trained, competent and experienced staff & 4.36 & 0.733 \\
\hline & I24 Restaurant supports the employees & 4.40 & 0.728 \\
\hline \multirow[t]{5}{*}{ Empathy } & I 25 Employees provide individual attention & 4.06 & 0.903 \\
\hline & I26 Special feeling & 4.09 & 1.034 \\
\hline & I27 Anticipation of guests' individual needs and wants & 4.03 & 0.993 \\
\hline & I 28 Sympathetic and reassuring employees & 4.26 & 0.846 \\
\hline & I 29 Guests' best interests at heart & 4.41 & 0.856 \\
\hline
\end{tabular}

Notes Column headings are as follows: (1) mean, (2) standard deviation.

sion was Reliability (mean 4.6), with I14, with 'the accurate guest bill' as its highest-rated indicator (mean value 4.82). The results indicate that the lowest perceptions are related to the dimension of Empathy (mean 4.17), with the lowest scores related to the indicator 127 - 'Anticipation of guests' individual needs and wants' (mean 4.03). Standard deviations (SD) show how ho- mogeneous guests are in the evaluation of different quality indicators.

In the next section of the study, EFA was performed to assess the factor structure of perceived service quality. The first step in this process was to check the distribution of data. Because we could not confirm a normal distribution for any of the selected qual- 
ity indicators of the first set (a Kolmogorov-Smirnov test was used), it was necessary to use the Principal Axis Factoring method for performing EFA. Based on the results of the first test, we evaluated the suitability of the information for inclusion in the factor model. Thus, based on the value of the Kaiser-MeyerOlkin (кмо) Measure of Sampling Adequacy (o.943), and the outcome of Bartlett's test of sphericity $\left(\chi^{2}=\right.$ 4206.494; degrees of freedom $=406$ ), we estimated that all included variables were suitable for performing EFA. Most indicators had satisfactory commonalities $(\geq 0.50)$, suggesting that the greater part of their variability can be explained by the influence of the common factors. In the next step, eight quality indicators with too low $(<0.50)$, commonalities ( 11,15 , I6, I7, I14, I15, I16, and I25) were excluded from the evaluation process. After a few successive iterations of the factor model evaluation (eight rotations were performed), we finally selected as the most appropriate the model with 19 service quality indicators; while two indicators with too low communalities (I17 and I21) had to be removed from the factor model.

The suitability of the information for inclusion in the final model is also supported by the high value of the кмо indicator (0.942) and the outcome of Bartlett's test $\left(\chi^{2}=2945\right.$.012; degrees of freedom $\left.=171\right)$. Based on a rotated factor solution, we have decided to include two main factor groups (service quality dimensions) in the final model, as they allow a more meaningful interpretation of results. The final (rotated) factor model with two quality dimensions is presented in Table 3. In the final model, factor weights with factor loadings above 0.3 and factors that contain more than three service quality indicators were retained. Indicators belonging to the quality dimensions Empathy (I28, I29, I27, and I26), Reliability (I11, I12, I13) and Assurance (I24, I19) were logically merged into a new common quality dimension called 'ERA.'

Based on the rotated matrix of factor weights presented in Table 3, it is evident that according to guests' perceptions of service quality, only two quality dimensions are important for delivering restaurant service quality: (1) ERA (51.06\%) and (2) Tangibles (7.31\%). Based on the presented quality dimensions and the values of their total explained variances, it is evident
Table 3 Final-rotated factor solution

\begin{tabular}{|c|c|c|c|c|c|}
\hline (1) & (2) & (3) & (1) & (2) & (3) \\
\hline I 28 & 0.849 & -0.022 & I 23 & 0.435 & 0.386 \\
\hline I 11 & 0.829 & -0.140 & I 18 & 0.429 & 0.325 \\
\hline I 29 & 0.822 & 0.007 & I 2 & -0.086 & 0.767 \\
\hline I 12 & 0.753 & -0.095 & I 8 & -0.036 & 0.740 \\
\hline $\mathrm{I} 24$ & 0.708 & 0.074 & $\mathrm{I} 20$ & -0.017 & 0.731 \\
\hline I 4 & 0.655 & 0.088 & I 22 & 0.112 & 0.655 \\
\hline I 27 & 0.624 & 0.142 & I 10 & 0.122 & 0.620 \\
\hline I 26 & 0.622 & 0.195 & I9 & 0.173 & 0.577 \\
\hline I 19 & 0.596 & 0.094 & $\mathrm{I} 3$ & 0.270 & 0.465 \\
\hline I 13 & 0.452 & 0.271 & $\%^{*}$ & 51.060 & 7.310 \\
\hline
\end{tabular}

Notes Column headings are as follows: (1) quality indicators, (2) empathy, reliability and assurance (era), (3) tangibles. ${ }^{*}$ Percentage of explained variance.

that, according to guests' quality perceptions, the indicators reflecting the quality of service staff (ERA) have by far the greatest importance in assuring restaurant quality, followed by the quality of Tangibles. We believe that further dissection of the results would not contribute to the improvement of the quality of research. Therefore, we have decided to keep the final factor model with two main factor groups (quality dimensions).

\section{Discussion}

In order to better understand the results of the statistical analysis presented in Chapter 3 , our findings were compared to the results of the previous study performed in the coastal area of Portorož and Piran. Research characteristics and findings of both studies are summarised in Table 4.

The comparison of results from both studies reveals that the highest rated quality indicator was 'Bill accuracy.' It can thus be suggested that restaurant bills were accurate in both studies. Interestingly, in the Portorož and Piran research, the lowest-rated indicator was 'Paying more than planned.' Therefore, we might assume that guests did not pay more than they had initially anticipated. In our study, the lowest-rated indicator was 'Anticipation of guests' individual needs and wants,' which indicates that guests were not completely 
Table 4 Comparison of Results between the Two Restaurant-Quality Studies from Slovenian Istria

\begin{tabular}{lll}
\hline Research characteristics & Portorož \& Piran (coastal area)* & Hinterland (rural area) \\
\hline Methodology & DINESE RV tool (mod. questionnaire) & DINESE RV tool (original version) \\
\hline Time of research & April 2014 & April 2019 \\
\hline Research approach & $\begin{array}{l}\text { Two-step (perceptions-minus- } \\
\text { expectations) }\end{array}$ & One-step (performance analysis) \\
\hline Sample size (n) & 32 restaurants; 156 domestic guests & 25 restaurants; 250 domestic guests \\
\hline Restaurant type & Restaurants, Inns, Snack facilities & Restaurants, Inns, Snack facilities \\
\hline Highest rated indicator & Bill accuracy & Bill accuracy \\
\hline Lowest rated indicator & Paying more than planned & Anticipation of guests' individual needs \\
\hline Identified quality dimensions (factor & $\begin{array}{l}\text { Four dimensions (respectively): Assur- } \\
\text { ance, Restaurant Ambiance, Respon- }\end{array}$ & Two dimensions: ER A and Tangibles \\
structure) & siveness, and Satisfaction and Loyalty & \\
\hline
\end{tabular}

Notes * Study conducted in 2015 by Kukanja and Planinc.

satisfied with the way the service staff anticipated their needs and wants.

Furthermore, the comparison of results from both factor analyses reveals that EFA in Portorož and Piran study extracted four factors, which explained 61.70 per cent of the total variance in the data. Research results revealed that guests' perceptions of restaurant service quality in the coastal area were mainly based on the quality of the following four quality dimensions: Assurance, Ambiance, Responsiveness, and Satisfaction and Loyalty. In our study, only two factors were extracted (ERA and Tangibles), which explains 58.37 per cent of the total variance in the data. Although the first factor (ERA) is composed of three quality dimensions (see Table 3), the research result indicates a relatively bipolar service quality structure in rural restaurants in comparison to restaurants located in the coastal area. The factor structure in rural restaurants highlights the importance of the quality of service staff (ERA) and the quality of the physical environment (Tangibles). This is critical because it indicates the importance of functional quality (people) in restaurants located in a rural area. To ensure restaurant quality in rural areas, managers must primarily ensure the quality of service staff and the physical environment. This is also relevant because in the Republic of Slovenia the minimum standards related to the quality of the physical environment are determined by the national rules (see https://www.tgzs.si/zakonodaja). In contrast, there are no minimum standards related to the professional characteristics of service staff.

Taken together, these results suggest that domestic guests in coastal and rural restaurants do not evaluate restaurant service quality based on the same quality indicators. There are several possible explanations for these results. First, the time gap between the two types of research might have significantly influenced guests' quality expectations and/or the level of restaurant offer in both areas. However, there are also other possible explanations for these results, such as: the primary focus of restaurateurs operating in rural area is on local guests (residents), the seasonality of restaurant offerings in the coastal area, the high fluctuation of service staff working in coastal restaurants, restaurant managers' characteristics, rural area managers' demographic characteristics, which might be significantly influenced by the specifics of the 'Mediterranean' way of life, etc. More research on this topic needs to be undertaken before the association between restaurant guests' quality perceptions in both areas is more clearly understood. However, the results of this study are quite encouraging as they indicate a relatively high level of perceived service quality in restaurants located in the Istrian hinterland (average mean value is 4.31). 


\section{Conclusion and Implications}

The purpose of this study was to determine how different quality indicators of the institutional DINESERV tool influence domestic guests' quality perception in rural restaurants. Based on qualitative research, we were unable to determine the importance of different quality indicators in restaurants operating in a rural area. Returning to the $\mathrm{RQ}$ posed at the beginning of this study, it is now possible to state that, in rural Istria, domestic guests perceive restaurant service quality based on two primary quality dimensions: ERA and Tangibles (see also Table 3). This study has also identified nineteen service quality indicators that best explain guests' quality perceptions in rural restaurants: visually attractive dining area, clean neat and appropriately dressed staff, restaurant's décor typical to its image and price range, clean restrooms, clean dining areas, comfortable seats in the dining room, service in the promised time, quick correction of incorrect service, dependable and consistent restaurant, extra effort in handling special requests, employees completely answer questions, comfortable and confident feeling, feeling safe, well-trained, competent and experienced staff, restaurant supports the employees, special feeling, anticipation of guests' individual needs and wants, sympathetic and reassuring employees, and guests' best interest at heart.

The second part of this study was concerned with comparing the results of our study to previous research findings (Kukanja \& Planinc, 2015). In comparison to previous research conducted in a coastal area, our study confirmed the importance of different quality dimensions. It can, therefore, be assumed that domestic guests in restaurants located in a coastal and rural area have different quality perceptions regarding restaurant service quality. The present study confirms previous findings (Djekic et al., 2016; Kim, $\mathrm{Ng}$, \& Kim, 2009) and contributes additional evidence which suggests that service quality dimensions cannot be generalised. The present findings enhance our understanding of restaurant service quality in rural areas.

The findings of this study have important implications for future practice and quality development strategies, as they provide information about service quality in restaurants operating in a rural area. Once guests' quality perceptions are identified, restaurant managers must strive to provide quality offerings. The key policy priority should, therefore, be to implement a quality management system (e.g., systematic and ongoing analyses of restaurant quality, training and educational programmes for restaurant managers and staff, comparison and exchange of best practices, etc.) at individual (restaurant's) and destination (regional) level.

This study has also found that the cooperation between scholars (academia) and restaurant providers (regarding research into restaurant service quality in rural areas) is generally weak. As restaurants present a basic and vital element of a destination's tourism offer, restaurant service quality should be regularly evaluated. Gastronomy represents a critical element in destination marketing and significantly influence a destination's image. Therefore, restaurant service quality should also be measured by local marketers and developers. In terms of quality control, Ohe and Kurihara (2013) reported the importance of a broader perspective related to local resource management. Especially the nurture of local food heritage and the quality of the partnership between tourism providers and local food producers found to be extremely important for quality assurance and economic development at the destination level.

Despite its contributions, some significant limitations need to be considered. The major limitation of this study is the absence of foreign guests' evaluation of perceived restaurant quality. Another limitation is the time of research, as it was conducted in only a onemonth period. Therefore, additional caution must be applied, as the findings might not be completely generalisable. Notwithstanding these limitations, this research has generated many questions in need of further investigation. Future studies should empirically investigate whether differences exist between different segments of guests during different times of the year (especially during high and low season). A further study could also assess restaurant quality in other neighbouring and competitive rural destinations, such as Slovene Karst and Brda, Croatian Istria, and the Italian region of Friuli-Venezia Giulia. Regarding recommendations for future research, further work could 
also investigate if differences exist between restaurant managers' and guests' perceptions of service quality.

\section{References}

Adil, M., Al Ghaswyneh, O. F. M., \& Albkour, A. M. (2013). SERVQUAL and SERVPERF: A review of measures in services marketing research. Global Journal of Management and Business Research, 13(6), 65-76.

Ali, F., Hussain, K., Konar, R., \& Jeon, H. M. (2017). The effect of technical and functional quality on guests' perceived hotel service quality and satisfaction: A SEM-PLS analysis. Journal of Quality Assurance in Hospitality \& Tourism, 18(3), 354-378.

Bellini, N., \& Resnick, E. (2018). The luxury turn in wine tourism: Still good for local development? In N. Bellini, C. Clergeau, \& O. Etcheverria (Eds.), Gastronomy and local development (pp. 262-267). London, England: Routledge.

Bojnec, S., \& Latruffe, L. (2013). Farm size, agricultural subsidies and farm performance in Slovenia. Land Use Policy, 32, 207-217.

Bougoure, U. S., \& Neu, M. K. (2010). Service quality in the Malaysian fast food industry: An examination using DINESERV. Services Marketing Quarterly, 31(2), 194-212.

Candido, C. J., \& Morris, D. S. (200o). Charting service quality gaps. Total Quality Management, 11(4/6), 463-472.

Cawley, M., \& Gillmor, D. A. (2008). Integrated rural tourism: Concepts and practice. Annals of Tourism Research, 35(2), 316-337.

Chen, C. T., Cheng, C. C., \& Hsu, F. S. (2015). G RSE Rv scale: An effective tool for measuring consumer perceptions of service quality in green restaurants. Total Quality Management \& Business Excellence, 26(3/4), 355-367.

Cronin Jr, J. J., \& Taylor, S. A. (1994). Servperf versus SERVQUAL: Reconciling performance-based and perceptions-minus-expectations measurement of service quality. Journal of Marketing, 58(1), 125-131.

Djekic, I., Kane, K., Tomic, N., Kalogianni, E., Rocha, A., Zamioudi, L., \& Pacheco, R. (2016). Cross-cultural consumer perceptions of service quality in restaurants. $\mathrm{Nu}$ trition \& Food Science, 46(6), 827-843.

Eid, R., \& Abdelkader, A. A. (2017). Muslim service quality dimensions in the tourism and hospitality industry: Construct development and measurement validation. International Journal of Islamic Marketing and Branding, 2(3), 215-231.

Frochot, I. (2005). A benefit segmentation of tourists in rural areas: A Scottish perspective. Tourism Management, 26(3), 335-346.
Gačnik, A. (2012). Gastronomy heritage as a source of development for gastronomy tourism and as a means of increasing Slovenia's tourism visibility. Academia Turistica, 5(2), 39-6o.

Gričar, S., \& Bojnec, Š. (2009). Dejavniki gibanja cen v gostin$s t v u$. Koper, Slovenia: University of Primorska, Faculty of Management.

Grönroos, C. (1990). Relationship approach to marketing in service contexts: The marketing and organizational behavior interface. Journal of Business Research, 2o(1), 3-11.

Hanks, L., Line, N., \& Kim, W. G. W. (2017). The impact of the social servicescape, density, and restaurant type on perceptions of interpersonal service quality. International Journal of Hospitality Management, 61(2017), 3544.

Hansen, K. V. (2014). Development of SERVQUAL and DINESERV for measuring meal experiences in eating establishments. Scandinavian Journal of Hospitality and Tourism, 14(2), 116-134.

Johns, N., \& Tyas, P. (1996). Use of service quality gap theory to differentiate between foodservice outlets. Service Industries Journal, 16(3), 321-346.

Kerma, S., \& Gačnik, A. (2015). Wine tourism as an opportunity for tourism development: Examples of good practice in Slovenia. Journal of International Food \& Agribusiness Marketing, 27(4), 311-323.

Kim, H. J., McCahon, C., \& Miller, J. (2003). Assessing service quality in Korean casual-dining restaurants using Dineserv. Journal of Foodservice Business Research, 6(1), 67-86.

Kim, W. G., Ng, C. Y. N., \& Kim, Y. S. (2009). Influence of institutional DINESERV on customer satisfaction, return intention, and word-of-mouth. International Journal of Hospitality Management, 28(1), 10-17.

Knutson, B. J., Stevens, P., \& Patton, M. (1996). Dineserv: Measuring service quality in quick service, casual/theme, and fine dining restaurants. Journal of Hospitality \& Leisure Marketing, 3(2), 35-44.

Knutson, B., Stevens, P., Wullaert, C., Patton, M., \& Yokoyama, F. (1990). LODGSERV: A service quality index for the lodging industry. Hospitality Research Journal, 14(2), 277-284.

Korez-Vide, R. (2017). Storytelling in sustainable tourism management: Challenges and opportunities for Slovenia. Journal of Advanced Management Science, 5(5), 380-386.

Križman Pavlović, D., \& Živolić, S. (2008). Upravljanje marketingom turističke destinacije: stanje i perspektive u Republici Hrvatskoj. Economic Research, 21(2), 99-113.

Kukanja, M. (2016). Od beneškega bakalaja do sladke Istre: 
razvoj prehrambnega gostinstva na Slovenski obali. Koper, Slovenia: University of Primorska Press.

Kukanja, M. (2017). Quality measurement in restaurant industry from the marketing perspective: A comparison of guests' and managers' quality perceptions. Ekonomska misao i praksa, 26(1), 41-61.

Kukanja, M., \& Planinc, T. (2015). Restaurant quality: A cross-national comparison between two neighbouring North Mediterranean tourist destinations - Portorož and Opatija; Domestic customers' perspective. Academica Turistica, 8(2), 85-110.

Kukanja, M., \& Planinc, T. (2018). Influence of managers' perceptions of quality on restaurant operational profitability: Evidence from Slovenian s MEs. Turizam, 66(2), 115-120.

Kukanja, M., Gomezelj Omerzel, D., \& Kodrič, B. (2017). Ensuring restaurant quality and guests' loyalty: An integrative model based on marketing ( $7 \mathrm{P}$ ) approach. Total Quality Management \& Business Excellence, 28(13/14), 1509-1525.

Lehtinen, U., \& Lehtinen, J. R. (1991). Two approaches to service quality dimensions. Service Industries Journal, 11(3), 287-303.

Lin, S. P., Chan, Y. H., \& Tsai, M. C. (2009). A transformation function corresponding to IPA and gap analysis. Total Quality Management, 2o(8), 829-846.

Loureiro, S. M. C. (2012). Tourism in rural areas: Foundation, quality and experience. In M. Kasimoglu, (Ed.), Visions for global tourism industry: Creating and sustaining competitive strategies (pp. 441-46o). Rijeka, Croatia: InTech.

Marković, S., Raspor, S., \& Šegarić, K. (2010). Does restaurant performance meet customers' expectations? An assessment of restaurant service quality using a modified DINESERV approach. Tourism and Hospitality Management, 16(2), 181-195.

Mestna občina Koper. (2016). Strategija razvoja in trženja turizma $v$ Mestni občini Koper do leta 2025. Retrieved from https:/www.koper.si/wp-content/uploads/2019/ 03/Strategija-turizma-v-MOK-do-2025.pdf

Ministry of Economic Development and Technology. (2019). The strategy for the sustainable growth of Slovenian tourism for 2017-2021. Ljubljana, Slovenia: Author.

Nikbin, D., Marimuthu, M., \& Hyun, S. S. (2016). Influence of perceived service fairness on relationship quality and switching intention: An empirical study of restaurant experiences. Current Issues in Tourism, 19(10), 1005-1026.

Ohe, Y., \& Kurihara, S. (2013). Evaluating the complementary relationship between local brand farm products and rural tourism: Evidence from Japan. Tourism Management, 35, 278-283.

Oliver, R. L. (1980). A cognitive model of the antecedents and consequences of satisfaction decisions. Journal of Marketing Research, 17(4), 460-469.

Parasuraman, A., Zeithaml, V. A., \& Berry, L. L. (1985). A conceptual model of service quality and its implications for future research. Journal of Marketing, 49(4), 41-50.

Parasuraman, A., Zeithaml, V. A., \& Berry, L. L. (1988). Servqual: A multiple-item scale for measuring consumer perceptions of service quality. Journal of Retailing, 64(1), 12-40.

Park, J., \& Jeong, E. (2019). Service quality in tourism: A systematic literature review and keyword network analysis. Sustainability, 11(13), 1-21.

Potočnik Slavič, I. (2014). Farm tourism in Slovenia: Mosaic structure and future prospects. Journal of Rural \& Community Development, 9(3), 280-294.

Raajpoot, N. A. (2002). TANGSERv: A multiple item scale for measuring tangible quality in foodservice industry. Journal of Foodservice Business Research, 5(2), 109-127.

Roberts, L., Hall, D., \& Morag, M. (2017). New directions in rural tourism. London, England: Routledge.

Ryu, K., \& Lee, J. S. (2017). Examination of restaurant quality, relationship benefits, and customer reciprocity from the perspective of relationship marketing investments. Journal of Hospitality \& Tourism Research, 41(1), 66-92.

Saeida Ardakani, S., Nejatian, M., Farhangnejad, M. A., \& Nejati, M. (2015). A fuzzy approach to service quality diagnosis. Marketing Intelligence \& Planning, 33(1), 103-119.

Sanchez-Cañizares, S., \& Castillo-Canalejo, A. M. (2015). A comparative study of tourist attitudes towards culinary tourism in Spain and Slovenia. British Food Journal, $117(9), 2387-2411$.

Sharif, K., \& Kassim, N. M. (2012). Non-academic service quality: Comparative analysis of students and faculty as users. Journal of Marketing for Higher Education, 22(1), $35-54$.

Sharpley, R. (2002). Rural tourism and the challenge of tourism diversification: The case of Cyprus. Tourism management, 23(3), 233-244.

Stevens, P., Knutson, B., \& Patton, M. (1995). Dineserv: A tool for measuring service quality in restaurants. The Cornell Hotel and Restaurant Administration Quarterly, 36(2), 5-6o.

Sukiman, M. F., Omar, S. I., Muhibudin, M., Yussof, I., \& Mohamed, B. (2013). Tourist satisfaction as the key to destination survival in Pahang. Procedia: Social and Behavioral Sciences, 91, 78-87. 
Truong, T. H., \& Foster, D. (2006). Using hols AT to evaluate tourist satisfaction at destinations: The case of Australian holidaymakers in Vietnam. Tourism Management, 27(5), 842-855.

Turistično združenje Portorož. (2019). Strategija razvoja turizma v občini Piran do leta 2025. Retrieved from https:// www.portoroz.si/si/files/default/PDF/Partnerji/

Strategija\%2orzavoja\%2oturizma\%2oob\%c4\%8dine \%2oPiran\%2odo\%2oleta\%202025.pdf

Unuvar, S., \& Kaya, M. (2017). Measuring service quality by servperf method: A research on hospitality enterprises. Australian Academy of Accounting and Finance Review, 2(4), 354-362.
Wong Ooi Mei, A., Dean, A. M., \& White, C. J. (1999). Analysing service quality in the hospitality industry. Managing Service Quality, 9(2), 136-143.

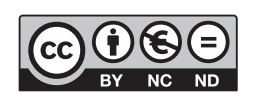

This paper is published under the terms of the Attribution- NonCommercial-NoDerivatives 4.0 International (CC BY-NC-ND 4.0) License. 